\title{
An Interview with Verna Miller (Pepeyla)
}

\author{
Ashley Blazina ${ }^{1^{*}}$ \\ ${ }^{1}$ School of Environmental and Forest Sciences, University of Washington, Seattle, WA, USA. \\ *ajblazin@uw.edu
}

Received November 2, 2017

Accepted November 24, 2017

OPEN ठACCESS

DOI 10.14237/ebl.9.1.2018.1149

Copyright (c) 2018 by the author(s); licensee Society of Ethnobiology. This is an open-access article distributed under the terms of the Creative Commons Attribution-NonCommercial 4.0 International Public License (https://creativecommons.org/licenses/by-nc/4.0), which permits non-commercial use, distribution, and reproduction in any medium, provided the original author and source are credited.

Verna Miller (Pepeyla) is a member of the Nlakapamux First Nation of interior British Columbia. She is currently the president of the International Society of Ethnobiology, and is also the Chair of the Nlakapamux Child and Family Services Society. Previously, Mrs. Miller worked as Director of Tmixw Research, an indigenous research group, as well as the Project Facilitator for the Nlakapamux Health and Healing Society, which provides spiritual and mental health counseling for victims of the residential schools. Mrs. Miller attended an Indian residential school from the age of 7 between 1954 and 1966. Verna has a Bachelor of Arts in Geography and Environmental Studies from the University of Victoria, as well as a Master of Education degree from Thompson Rivers University.

I first heard Mrs. Verna Miller speak as one of the keynotes at the 2016 Society of Ethnobiology conference in Tucson, AZ. Her ideas on how to expand the educational system beyond the fourwalled classroom both inspired me and stuck with me. I had the chance to briefly chat with Mrs. Miller after her talk, and have been intrigued ever since. Given the theme of this issue of Ethnobiology Letters, I was honored to have the chance to speak with Verna on the topics of ethics and education in June 2017. The following is an edited version of our conversational interview. I've attempted to retain as many of Verna's powerful, often poetic, words and insights as possible.

Ashley: I'll just jump right in, but if you want to lead the conversation in a certain direction, please feel free. You mentioned that you learned a lot at a young age from your grandparents (Legacy of Hope Foundation 2013; Miller 2013). Were you aware of the importance of these teachings when you were younger, or is this something that's grown with you?

Verna: It wasn't until I got home again that I realized how important the teachings were. I always had them with me, but I missed out on most of the teachings because I was sent away at a very young age to a residential school, and we were not allowed to speak our language; we weren't allowed to practice any of our traditional ways of life. They were doing their best to change us. I thought I had lost a lot of it, and when I came home, my memories of the time I spent with my grandparents started to come back and be renewed. I would listen to my aunts and uncles when they were still alive, and they would tell me stories as well.

Ashley: That brings up the idea of place-based education. You called it in-situ education (Miller 2013), which is such a key way to put it. How important is it to learn from multiple teachers, whether that be different people, plants, animals, processes, or place, and how can that be incorporated into today's learning environment?

Verna: It's going to mean a major, major paradigm shift. It won't be easy because society is so engrained in the present form of education that there is reluctance. But I think there is a way to take the classroom out of the square box, or rectangle, or whatever the case may be, and put people in nature, in situ. Any topic that you learn in school can easily be learned outside, and it will cover more of the different styles of learning. Not everyone can learn from the present situation. From my understanding from reading John Taylor Gatto, he indicated that the present system of education caters to a minority of learners-a great minority of learners. In Harold Gardner's Multiple Intelligences (1983), he gives really clear examples of 
the different ways that people learn. It's training teachers to think differently and to get out of the classroom.

An associate of mine once said, "How can you talk about nature if you're not intimate with nature?" How much of our lives depend on nature, the natural world? And yet, the present system of education doesn't allow for that in a more intimate way. It's all class-based, and I mean that with more meanings than one. I think this goes to the element of ethics. If you don't understand nature, how can you be ethical about how you conduct your study?

Ashley: I was reading an interview with Alexis Shotwell (Prescod-Weinstein 2017) who wrote Against Purity: Living Ethically in Compromised Times (Shotwell 2016). Shotwell talks about how our ethical regard can inform society's belief in that being's right to live or thrive. This goes into the ideas we have about race, disability, gender, but also how we might view a tree's right to survive [or be destroyed]. What are the different classes we're really giving everything, and how is that applying?

Verna: The problem with ethics is how people interpret the ethics and whether it suits their individual or institutional purpose. What they can get away with, so to speak. I know that's not very fair, but that's been my experience. I've said to young ethnobiologists, "Be aware of your own arrogance." Just because you're of a certain cache in the academic world does not mean that you own that knowledge. You are gathering it from people. And you have to develop a relationship. You can't just walk in and take their information and copyright it and say it's your own. This is where the difficulty lies, because universities have a certain process that they demand young academics follow. A lot of times it goes against the ethical demeanor of the work that these young people are doing. They're starting to understand that, "This doesn't belong to me." It doesn't belong to the university, it has been shared, that element of respect is missing in the academic world.

Ashley: I agree. I really like how you explain that, in [many] Indigenous education practices (Miller 2013), the student and the teacher have this level of respect that's carried throughout the teachings. I was reflecting on how often that wasn't present in my own education, and how that [lack of respect] could be carried into how an academic operates, and how damaging that is.
Verna: And when it's out of context, it becomes a matter of one's credibility. I was in Ottawa at an Access to Benefits sharing meeting [with] an associate. We were sitting at a table, and talking about the different parts of access to natural resources and benefits sharing.

And this young man says, "Well, that doesn't make sense, all of these studies should take place in a laboratory. All of these proofs, these experiments, should take place in a laboratory," and my associate just jumped on him. She said, "How dare you! Have you ever been outside of your lab?" he said, "Well no," and she said, "How do you have any ethical backbone to say something like that? You have no intimacy with what goes on in nature if you think the lab is the do-all, end-all." He was so taken aback that he didn't come back after that (laughter).

It was so true. You can't depend on just the laboratory. If you want to experiment, it's better to do it in nature and understand nature. Part of my teachings is that when the old people observed what was going on in nature they were able to conduct themselves accordingly. I remember my grandmother [and I] were picking berries and off in the distance we see this bear thrashing around in this berry bush and she made a comment to the effect that, "Oh look, the bear is pruning the bushes." It never clicked until Nancy Turner mentioned it [later], and I remembered that comment by my grandmother. So, my grandmother, she used to do the same thing. She'd sit there and she'd look at the bush before she started picking and she'd prune off the ones that weren't producing, and she'd come back to the same bush the next year and there'd be twice as many berries, but there'd be other branches that she'd have to prune.

Ashley: [Speaking of] your grandmother [and] learning from the environment, I was thinking about the story [of] how intimately she knew what keys to look for when collecting different saps (Miller 2013). A person has to adapt to the environment when they're living that intimately with it. With colonialbased education, [we're] taught that as a person becomes - I'm putting quotes in the air - more 'educated,' they can control their environment more. Could you talk about the types of damages this causes, [although] that story you shared with your associate and that young man is pretty telling.

Verna: Well, I suspect this poor young man spent most of his life in the city. A lot of the bigger academic institutions are in big cities that don't have the same 
access to day-to-day living as the more rural areas do. And I think both my grandparents were so experienced in the way that they lived that they could predict whether it was going to be a good year for a certain food source to harvest, and they knew all the places where these sources of food were. I believe the expression used is 'knowing the indicators.'

I remember riding with both of them with their pack horse. We'd go up and camp in the mountains, collecting different foods and medicines. We'd hunt, we'd fish. Of course, in those days, we didn't have electricity, so we preserved a lot of our own food whether we canned it, dried it, [or] salted it, we never starved. My grandparents were so adept at doing these things because they were so intimate with their landscapes. My uncle was telling me [that] my grandfather would go out at night and he would never prayed - but he would give praise to the sky. My grandmother, during the day at some point, would give praise to the earth. There are different spiritual ways of giving thanks. In indigenous cultures in our area we always give an offering before any activity and we always give thanks at the conclusion of an activity.

Ashley: What are some suggestions you have for people who have gone through colonial education to gain this respect back for and give praise to these different processes? How can we put it back into the education processes?

Verna: First of all, we have to convince people that this is the way to go. And it's going to take a major paradigm shift. It's going to take time to get everyone comfortable with this way of learning, this system of learning. It can be more accommodating to different learning styles. I mean, it's not going to happen in my lifetime (laugher and groans).

It's an idea that I personally think is doable but I know people are going to resist, because people are in a state of comfort. What is that expression? Why fix it if it ain't broke? I don't think people realize how broke it is, because that intimacy with nature is missing. Technology doesn't work with nature very well. I can see where technology would work, but it shouldn't be the do-all, end-all. If the earth is going to survive in a sustainable manner, there has to be more intimacy with nature. More respect and intimacy with nature.

Ashley: So, gaining back that respect and the intimacy.
Verna: It hearkens back to watching what was happening in the United States with the [Dakota Access] Pipeline, the black snake as they're calling it, and how the corporate elite really don't care about nature. To them it's how much money can they make, and how fast can they make it while they're still alive. And you know, it also presents another dilemma: People need jobs. Unfortunately, a lot of those jobs mean compromising nature. And that's a real dilemma for me. I mean, I understand both sides, but there's got to be a better way.

Ashley: There's just so many things to tackle. Like you said, it's broken in so many ways that it's overwhelming - where do we start?

Verna: It is extremely overwhelming, but you know, little steps, little steps. You just [have] to take little steps at a time and make it work. And yet, the big thing is [changing] the colonizing system and the blatant racism. I always think that racism is born of fear and a lack of understanding.

Ashley: You mention in your thesis (Miller 2013) how the colonial education [system] is really dumbing us down. What are the best ways you've found to diminish these effects of being dumbed down?

Verna: Well, as Gatto (1991) says, it's what's in the curriculum and who decides what's in the curriculum. I think it's very selective on the part of the elites to determine what we should be learning. There are some reasonable theories that make sense. But morals, ethics, values? We learned that at home. What we observed in the residential school was - contradictory. Controlling how you thought, how you felt, how you judged. How you went through life feeling guilty about how you conducted yourself rather than say, 'Okay, I learned a lesson from that, I don't need to feel guilty, I'll just move on.'

That was more destructive than it should have been because it compromised and diminished our own spiritual lives that were more connected to nature. People are going to live how they're going to live, but if you don't experience things and learn from them, then you go through life feeling like crap.

I don't resent people who are religious - if that's what gives them comfort, that's fine. But I resent the propaganda that they used against my own spiritual life. My grandparents' teachings.

Ashley: I wanted to talk to you a little about the allegorical voice you used for stretching the hide (Miller 2013). I thought it was so beautiful, and I still 
haven't fully grasped everything from it. Could talk more about that voice, and how you developed it?

Verna: It's connected to sustainability, that connection to nature. How you take from nature and you don't waste anything. But in the process, you have to give thanks. We'd get a deer or a moose, [and] when my grandmother was working on the hide she would be singing - thanking - the spirit of that deer for providing for us. And it was more a metaphor of the different things you could learn in nature. For example, when learning basketry, you learn trigonometry. In the stretching of the hide, you learn how things work together, how you can make something for yourself. We still make our own regalia. Your regalia is who you are. You wear it at ceremony, [and] most people are buried in their regalia.

And the stretching of the hide is teaching process. It gives you physical activity. You learn how to mix a solution when you use the brains - it's chemistry. The scraping of the hair really teaches you patience. There's so many different elements of this and I'm trying to think of them all and I can't (laughter).

Ashley: Some school districts are incorporating Native American and First Nation education as a requirement, but I have a big fear that this will be a 'check off a box' on a sheet. What are ways that the teachers could "check" themselves [so to speak] before they check that box?

Verna: That's really tough. I was talking to one of the members of my cohort who said, "I don't feel qualified to teach this because I'm coming to it from my perspective."

In our area, both our districts have what they call a First Nations Principal. [For] any issues about indigenous peoples in our area, then the [First Nations Principals] are there to give as much assistance as they can to teach.

And it also goes back to, are the teachers themselves prejudice in any way? If they are, should they even be teaching this stuff? It's important to have the First Nations perspective, but teachers need to educate themselves on the most appropriate way understand the literature, go in with their eyes wide open. Have a much broader understanding before you go in to teach it, and part of that is just going to speak with another indigenous person. Maybe you need to speak to several indigenous people. It's really a dilemma, and I feel for the teachers who have no concept of if they're teaching this the right way.
Ashley: Because even if they have great intentions, they [may be] presenting it with these biases that they might not even know they have.

Verna: Exactly. I was co-teaching a course at Thompson Rivers University to two cohorts of teacher candidates. And I was talking about the process of tanning a hide and I said something about [having] to get used to the smell because - it's like you're tasting a food for the first time and you're not quite sure if you like it or not. And one girl in the classroom scrunched up her nose and had this look of disgust on her face, and I gave her a very long look. I thought, "Boy, she's going to be in trouble if she shows any signs of racism or lack of understanding." It's making sure that teachers understand their responsibilities. And if they do have any prejudice, then they have to make it known. Don't be afraid of your own folly. If the older teachers and the principals are worth their weight in gold, they will help these young people get through this.

Ashley: And not being afraid to counteract it when it is identified as well. Sometimes they are very aware of [their prejudice] and aren't willing to put in the work to fix it, but other times they have no idea they are holding these very racist ideas.

Verna: Oh yeah, it's born of ignorance, it's born of a lack of empathy and the ability or the willingness to understand better. And you know, it's tough. Most indigenous people have just learned not to trust. You just can't walk into an indigenous community and expect that everybody will fall all over themselves to please you. You're going to find out that nobody trusts you. So, you have to build trust and you have to maintain that trust; otherwise, all bets are off.

Ashley: That makes sense with any relationship, you need to keep that trust up.

Verna: The high school close by just had a whole bunch of different venues for Aboriginal Day. Each venue had a different guest and I was asked to come in and do the ethnobotany part of it. [Other venues showed] how to do beading, [and] how make an underground house pit. It was for the whole school, [not] just the indigenous children. Things like that are starting to happen, but it's going to take time. Because the racism that children project is what they get at home. Fear, ignorance, and lack of understanding all go together. My uncle, when he was chief, said that the younger generation of indigenous people are not as patient, and he's absolutely correct. Younger generations are getting stronger and much more vocal; 
smarter. They're getting involved in the colonial system of politics, administration, laws, you name it, and challenging those colonial systems. There's a great swell of young indigenous people that are taking notes. And that goes into education as well.

Ashley: And how it has to blow up and it has to change.

Verna: Oh, it has to change, we know we're in the minority but we're not going to go around not being heard again. Doesn't matter whether anybody likes it or not.

Ashley: So, if you were to envision a perfect educational system that could grow with technology and the new constructs of today, how would that look?

Verna: There's an example of a school - I think it's near your area - where everybody checks in and they're outside all day, come rain, shine, snow, whatever. Their teacher has their lessons set up [so that] the children play and [the teachers] watch for teachable moments. The children learn from that teachable moment. And they have [teachable moments] throughout the day with great regularity. Now, that's kindergarten, grade 1. But I think as kids get older there are going to be more things for them to do, more tactile things, like measuring the circumference of a tree to determine how old it is. [With] science, you could learn just about everything you need to learn outside. There's so many opportunities for teachable moments. I wouldn't even know where to start (laughter).

As traditionally, there was also a time inside for storytelling, passing along information. One of our bands is going toward a seasonal school. They are going to be taking more of the classroom time outside as opposed to sitting in a classroom.

That's something that is prevalent amongst First Nations kids: They can't stand sitting in a classroom for hours on end listening to a bobblehead. It's just not in our nature to sit there and be lumps on a log. We have to be out there - touching, feeling, observing. Doing something with our hands, doing something with our minds. It's a more holistic look at life, more holistic way of learning.

\section{References Cited}

American Civil Liberties Union. 2017. Arizona's SB 1070. Available at: https://www.aclu.org/issues/ immigrants-rights/state-and-local-immigrationlaws/arizonas-sb-1070? redirect $=$ feature/arizonassb-1070. Accessed on June 28, 2017.

Gardner, H. 1983. Frames of Mind: The Theory of Multiple Intelligences. Basic Books, New York, NY.

Gatto, J. T. 1991. Dumbing Us Down: The Hidden Curriculum of Compulsory Education. New Society Publishers, Gabriola Island, BC.

Miller, V. (Pepeyla). 2013. Indigenous Traditional Teaching and Learning Methods in a Culturally Relevant Context: The Braided Theory. Unpublished Master's Thesis, School of Education, Thompson Rivers University, Kamloops, BC, Canada.

Miller, Verna. 2013. We Are the Children: Healing the Legacy of the Residential Schools. Interview by the Legacy of Hope Au, T. K., and L. Romo. 1999. Foundation. Available at: http:// wherearethechildren.ca/en/watc_story/vernamiller/. Accessed on June 1, 2017.

Prescod-Weinstein, C. 2017. Purity in a Trumped-Up World: A Conversation with Alexis Shotwell. Bitch Magazine. Available at: https:// www.bitchmedia.org/article/purity-trumpedworld/conversation-alexis-shotwell. Accessed on June 18, 2017.

Shotwell, A. 2016. Against Purity: Living Ethically in Compromised Times. University of Minnesota Press, Minneapolis, MN. 